\title{
The effect of molybdenum levels in sorghum (Sorghum vulgare Pers.) on uric acid and copper excretion in man
}

\author{
By Y. G. DEOSTHALE AND C. GOPALAN \\ National Institute of Nutrition, Indian Council of Medical Research, \\ Famai Osmania, Hyderabad-500007, India
}

(Received II Guly 1973-Accepted 22 October 1973)

\begin{abstract}
I. The effect of various dietary levels of molybdenum on uric acid and copper excretion was studied in experiments with four adult men given diets based on two sorghum varieties (Sorghum vulgare Pers.) differing widely in Mo content.

2. With a Mo intake of 160,540 or $1540 \mu \mathrm{g} / \mathrm{d}$ the urinary excretion of uric acid was unaltered.

3. The excretion of $\mathrm{Cu}$ in urine increased with increasing Mo intake.

4. Cu-balance studied with high- and low-Mo dicts showed that with a high-Mo diet urinary $\mathrm{Cu}$ excretion increased but faecal $\mathrm{Cu}$ was unaffected. This indicates that dietary Mo had no effect on $\mathrm{Cu}$ absorption.

5. The high serum concentration of $\mathrm{Cu}$ with diets high in Mo indicates that Mo either mobilizes tissue $\mathrm{Cu}$ or inhibits $\mathrm{Cu}$ uptake, or both.
\end{abstract}

In populations subsisting on plant foods, the principle sources of dietary molybdenum are cereals, millets and pulses. Mo is an integral part of xanthine oxidase (Xanthine: oxygen oxidoreductase; $E C \mathrm{I} \cdot 2 \cdot 3 \cdot 2$ ), an enzyme concerned in uric acid synthesis. Tissue concentrations of this enzyme in experimental animals are related to the dietary intake of Mo (Hart \& Bray, I967; Underwood, 197I). In regions with soil rich in Mo, prevalence of gout is reported to be high (Kovalsky \& Vorotnitskaya, I970) and uric acid production is shown to be affected by very high intakes of Mo (Kovalsky, Yarovaya \& Shmavonyan, 196I). In certain parts of India, urolithiasis is common in millet-eating populations (Patwardhan, I96I). The millet sorghum (Sorghum vulgare Pers.), one of the important staple foods in these regions, is relatively rich in Mo when compared with rice (Deosthale, unpublished). However, there is no direct evidence of the role of dietary Mo in uric acid synthesis in man, especially in relation to renal-stone formation.

Dietary Mo also affects copper metabolism in various animal species. High intake of Mo apparently hastens $\mathrm{Cu}$ deficiency, especially in cattle and sheep; other species are apparently less affected (Underwood, 197I). The mechanism underlying the effect of high Mo intake on $\mathrm{Cu}$ deficiency is unknown.

Two sorghum grain samples differing widely in their Mo content were available in large quantities. We are able, therefore, to study the effect of diets based on the high- and low-Mo varieties of sorghum on uric acid and $\mathrm{Cu}$ excretion in human subjects. 


\section{EXPERIMENTAL}

\section{Expt $\mathrm{I}$}

Two samples of sorghum grain, containing 0.21 and I.39 $\mu \mathrm{g}$ Mo/g were used to make up diets low and high in Mo content. The diets supplied daily $\mathrm{II}^{\circ} 92 \mathrm{MJ}$ $(2.850 \mathrm{Mcal}), 50 \mathrm{~g}$ protein and $7 \mathrm{~g}$ total minerals; total sulphur intake was $35 \circ \mathrm{mg} / \mathrm{d}$. Apart from sorghum, the diets consisted of rice, vegetable oil, butter, and vegetables such as tomato, onion, potato, cabbage, cauliflower, cucumber and palak. Milk was given with tea or coffee. Four adult male volunteers were given the diet based on the low-Mo variety of sorghum for io $d$ followed by the diet based on the high-Mo variety for a further to d period. Total Mo intake during the first period was $166 \mu \mathrm{g} / \mathrm{d}$ and during the second period it was $540 \mu \mathrm{g} / \mathrm{d}$. The contribution to total dietary Mo from foodstuffs other than sorghum grain was constant and was about $100 \mu \mathrm{g} / \mathrm{d}$ for both diets. Daily urine samples were collected during the last $3 \mathrm{~d}$ of each period. The subjects then continued on the high-Mo sorghum diet and were given a supplement of ammonium molybdate so that the total Mo intake was raised to $1540 \mu \mathrm{g} / \mathrm{d}$. This diet was given for $7 \mathrm{~d}$ and urine samples were collected on the last $3 \mathrm{~d}$.

\section{Expt 2}

$\mathrm{Cu}$ balances of four adult male subjects on the low- and high-Mo sorghum diets, as in the first experiment, were measured. The $\mathrm{Cu}$ intakes from cooked diets were $2.400 \mathrm{mg} / \mathrm{d}$ and $2.417 \mathrm{mg} / \mathrm{d}$ on the low- and high-Mo sorghum diets respectively. During the last $3 \mathrm{~d}$ of each dietary period $24 \mathrm{~h}$ samples of urine and faeces were collected for estimation of $\mathrm{Cu}$. Blood samples were taken on the last day of each dietary period from all the four subjects and analysed for serum $\mathrm{Cu}$.

\section{Analytical methods}

The $24 \mathrm{~h}$ urine and faeces samples were collected by the procedure described by Vasantgadkar \& Tulpule ( $\mathrm{rg}_{3}$ ). Total nitrogen, creatinine and uric acid in urine were estimated by the methods described by Vasantgadkar, Venkatachalam \& Tulpule (1963). Urine samples were analysed for calcium, phosphorus and inorganic S (Hawk, Oser \& Summerson, I954). Mo was estimated in sorghum and other foodstuffs by a thiocyanate method (Sandell, 1959). Cu was estimated spectrophotometrically in serum and urine (Glorgio, Cartwright \& Wintrobe, 1964), and in faeces and foodstuffs (Gubler, Lahey, Ashenbrucker, Cartwright \& Wintrobe, 1952).

\section{RESULTS AND DISCUSSION}

\section{Expt I}

Effect on urinary uric acid excretion. The excretion pattern of various constituents of urine at different intake levels of Mo is presented in Table $\mathrm{I}$. The dietary intakes of protein and energy were the same on low- and high-Mo sorghum diets. The excretion of total $\mathrm{N}$ and creatinine in urine was therefore the same in the three dietary periods. 
Table I. Effect of different levels of dietary molybdenum on $24 h$ urinary excretion in four male human subjects

Urine measurements
$\quad$ (mean values)
Volume (ml)
pH
Total N (g)
Creatinine (mg)
Uric acid (mg)
Calcium (mg)
Phosphorus (mg)
Inorganic Sulphur (mg)
Copper $(\mu \mathrm{g})$

$\begin{array}{ccc}160 \mu \mathrm{g} / \mathrm{d} & 540 \mu \mathrm{g} / \mathrm{d} & 1540 \mu \mathrm{g} / \mathrm{d} \\ 1599 & 1495 & 155^{2} \\ 6.54 & 6 \cdot 62 & 6 \cdot 40 \\ 4.54 & 4 \cdot 30 & 4 \cdot 27 \\ 634 & 623 & 641 \\ 503 & 457 & 488 \\ 27 \cdot 7 & 27 \cdot 0 & 32 \cdot 8 \\ 535 & 523 & 506 \\ 201 & 192 & 186 \\ 24 & 42 & 77\end{array}$

Table 2. Effect of diets containing low-or high-molybdenum sorghum on urinary, faecal and serum copper in four male human subjects

\begin{tabular}{|c|c|c|c|c|c|c|}
\hline & \multicolumn{3}{|c|}{ Low-Mo diet } & \multicolumn{3}{|c|}{ High-Mo diet } \\
\hline & $\begin{array}{l}\text { Urine } \\
(\mu \mathrm{g} / \mathrm{d})\end{array}$ & $\begin{array}{l}\text { Faeces } \\
(\mu \mathrm{g} / \mathrm{d})\end{array}$ & $\begin{array}{c}\text { Serum } \\
(\mu \mathrm{g} / 1)\end{array}$ & $\begin{array}{l}\text { Urine } \\
(\mu \mathrm{g} / \mathrm{d})\end{array}$ & $\begin{array}{l}\text { Faeces } \\
(\mu \mathrm{g} / \mathrm{d})\end{array}$ & $\begin{array}{c}\text { Serum } \\
(\mu \mathrm{g} / 1)\end{array}$ \\
\hline Mean & 25.4 & $188_{31}$ & 805 & $7 I^{\prime} 2$ & 1828 & I I 30 \\
\hline SE & 5.39 & 74 & I I I & $3.3^{\circ}$ & 49 & 83 \\
\hline
\end{tabular}

The mean uric acid excretion in urine was $5 \circ 3 \mathrm{mg} / \mathrm{d}$ with the low-Mo diet; it was $457 \mathrm{mg} / \mathrm{d}$ with the high-Mo supplemented diet. No significant change was observed in the total volume of urine in the three dietary periods and therefore the concentration of uric acid remained constant. The $\mathrm{pH}$ of the various urine samples was similar, which suggested that the uric acid solubility as well as the uric acid-holding capacity of the urine did not change significantly with different Mo intakes. The suggested daily requirement for Mo is about $120 \mu \mathrm{g}$ (Schroeder, Balassa \& Tipton, 1970). In the present study, a twelve- to thirteen-fold increase in dietary intake in excess of this suggested requirement failed to result in any appreciable change in uric acid excretion in urine. At much higher intakes, IO- $15 \mathrm{mg} \mathrm{Mo} / \mathrm{d}$, uric acid production in man is increased (Kovalsky et al. I96r). This suggests that uric acid metabolism in man is altered only at very high intakes of Mo.

'The excretion of $\mathrm{Ca}, \mathrm{P}$ and inorganic $\mathrm{S}$ was unchanged in all three dietary periods.

In marked contrast, the excretion of $\mathrm{Cu}$ was significantly increased in all subjects with increasing levels of $\mathrm{Mo}$ in sorghum diets. The mean $\mathrm{Cu}$ excretion with the lowMo diet was $24 \mu \mathrm{g} / \mathrm{d}$, which increased to $42 \mu \mathrm{g} / \mathrm{d}$ with the high-Mo diet. A further increase in dietary Mo of $1000 \mu \mathrm{g} / \mathrm{d}$ increased the $\mathrm{Cu}$ excretion in urine, the mean value being $77 \mu \mathrm{g} \mathrm{Cu} / \mathrm{d}$. These differences in $\mathrm{Cu}$ excretion could not be ascribed to the differences in the dietary intake of $\mathrm{Cu}$, as the $\mathrm{Cu}$ content of the two sorghum samples was similar. Cu deficiency due to excess dietary intake of Mo has been attributed to altered absorption of $\mathrm{Cu}$ (Dick, 1956) and also a change in tissue metabolism (Dowdy 
$\&$ Matrone, I968a, $b$; Dowdy, Kunz \& Sauberlich, I969). In view of these reports and the present finding of increased $\mathrm{Cu}$ excretion in urine with increased levels of dietary Mo, a second experiment was done to obtain results for $\mathrm{Cu}$ balance.

\section{Expt 2}

Copper excretion. The results are shown in Table 2.

An increase in Mo intake significantly increased $\mathrm{Cu}$ excretion in urine, confirming the observations made in Expt $\mathrm{I}$. The mean urinary $\mathrm{Cu}$ content increased from 25.5 $\mu \mathrm{g} / \mathrm{d}$ on the low-Mo diet to $7 \mathrm{r} \cdot 2 \mu \mathrm{g} / \mathrm{d}$ on the high-Mo diet. However, the amount of $\mathrm{Cu}$ excreted in faeces in the two dietary periods was unchanged, suggesting that absorption of $\mathrm{Cu}$ was not affected by the level of $\mathrm{Mo}$ intake. The increase in urinary $\mathrm{Cu}$ with a high intake of Mo was probably not due to increased absorption in the gut.

The serum $\mathrm{Cu}$ concentrations were higher in all four subjects when they were given the diet containing sorghum with a higher content of Mo. The increase ranged from I 10 to $520 \mu \mathrm{g} / 1(P<0.0 \mathrm{I})$. The higher serum concentrations of $\mathrm{Cu}$ following increased Mo intake suggest mobilization of tissue $\mathrm{Cu}$ and increased urinary excretion. On the other hand, in vitro studies have shown that Mo inhibits $\mathrm{Cu}$ uptake by tissues (Dowdy \& Matrone, Ig68a, $b$; Marcilese, Ammerman, Valsecchi, Dunavant \& Davis, I969). This may explain the high serum concentrations of $\mathrm{Cu}$ and the increased urinary excretion.

The important finding is that levels of Mo in varieties of sorghum can bring about increased urinary excretion of $\mathrm{Cu}$. The effect of this continued excretion of $\mathrm{Cu}$ in populations eating these sorghum varieties as part of their staple diet requires study. $\mathrm{Cu}$ deficiency in animals has been associated with anaemia and osteoporesis (Davis, 1950). Careful investigations among populations eating high-Mo varieties of sorghum may indicate clinical symptoms resulting from a deficiency of $\mathrm{Cu}$.

We wish to thank Mr M. P. C. Vijaya Raj and Mr S. Suryaprakash for technical assistance.

\section{REFERENCES}

Davis, G. K. (1950). In Symposium on Copper Metabolism p. 216. [W. D. McElroy and B. Glass, editors]. Baltimore: Johns Hopkins Press,

Dick, A. T. (1956). In Inorganic Nitrogen Metabolism p. 445 [W. D. McElroy and B. Glass, editors]. Baltimore: Johns Hopkins Press.

Dowdy, R. P. \& Matrone, G. (r968a). F. Nutr. 95, r91.

Dowdy, R. P. \& Matrone, G. ( .968b). F. Nutr. 95, 197.

Dowdy, R. P., Kunz, G. A. \& Sauberlich, H. E. (I 969). F. Nutr. 99, 49 I.

Glorgio, A. J., Cartwright, G. E. \& Wintrobe, M. M. (I964). Am. F. clin. Path. 4I, 22.

Gubler, C. J., Lahey, M. E., Ashenbrucker, J., Cartwright, G. E. \& Wintrobe, M. M. (1952). J. biol. Chem. r96, 209.

Hart, L. I. \& Bray, R. C. (т 967). Biachim. biophys. Acta 146, 6r т.

Hawk, P. B., Oser, B. L. \& Summerson, W. H. (I954). Practical Physiological Chemistry I3th ed., p. 947. New York: McGraw Hill Book Company Inc.

Kovalsky, V. V. \& Vorotnitskaya, I. E. (1970). In Trace Element Metabolism in Animals p. I76 [C. F. Mills, editor]. Edinburgh and London: Livingstone.

Kavalsky, V. V., Yarovaya, G. A. \& Shmavonyan, D. M. (s96r). Zh. obshch. Biol. 22, I79. 
Marcilese, N. A., Ammerman, C. B., Valsecchi, R. M., Dunavant, B. G. \& Davis, G. K. (1969). 7. Nutr. 99, r77.

Patwardhan, V. N. (1961). Nutrition in India 3rd ed., p. 413. Bombay: The Indian Journal of Medical Sciences.

Sandell, E. B. (1959). Colorimetric Determination of Traces of Metals 3 rd ed., p. 640. New York: Interscience Publishers Inc.

Schroeder, H. A., Balassa, J. J. \& Tipton, I. H. (1970). F. chron. Dis. 23, 48 r.

Underwood, E. J. (1971). Trace Elements in Human and Animal Nutrition 3rd ed., p. I16. New York: Academic Press.

Vasantgadkar, P. S. \& Tulpule P. G. (1963). F. postgrad. Med. 9, 6.

Vasantgadkar, P.S., Venkatachalam, P. S. \& Tulpule, P. G. (I963). Am. F. clin. Nutr. 12, I5o. 